\title{
A TUTELA DOS BENS CULTURAIS E A RESPONSABILIDADE PATRIMONIAL DO ESTADO*
}

\author{
CARLOS FREDERICO MARÉS DE SOUZA FILHO
}

\section{SUMÁRIO}

1 - INTRODUÇĀO ...................... 247

2 - O MEIO AMBIENTE. O PATRIMÓNIO CULTURAL.

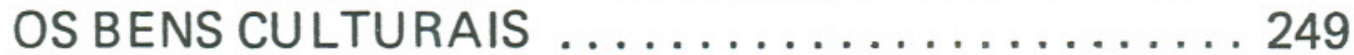

3 - O BEM CULTURAL .................. 252

Os Bens Móveis e Imóveis . . . . . . . . . . . . . . 252

Os Bens Fungíveis e Consumíveis . . . . . . . . . 253

O Interesse Público . . . . . . . . . . . . . . . . . . 254

Propriedade Pública e Propriedade Privada . . . . . . 255

4 - A MEDIDA DE VALOR DOS BENS CULTURAIS . . . . 257

5 - A TUTELA E A INTERVENÇĀO DO ESTADO NOS BENS CULTURAIS . . . . . . . . . . . . . . . 259

6 - RESPONSABILIDADE PATRIMONIAL DO ESTADO . 263 BIBLIOGRAFIA CITADA . . . . . . . . . . 267

\section{1 - INTRODUÇĀO}

As sociedades primitivas, culturalmente homogêneas e sem maiores divisões internas do que as impostas pela natureza, como idade e sexo, tinham na preservação de sua cultura um elemento vital de unidade do grupo. A questão da identidade cultural nestas sociedades sempre foi posta como atualidade e como integração da sociedade em si mesma e dela com a natureza.

O desenvolvimento da sociedade humana que ocasionou a divisão interna da sociedade em razão do trabalho e de origem

- Trabalho apresentado à Disciplina de Direito Administrativo do Curso de Pós-graduação do Setor de Ciências Jurídicas da UFPR. 
grupal, começou a gerar, também, um choque cultural interno e a cultura deixou de ser apenas um instrumento de integração da sociedade e da natureza, para ser também elemento de dominação. A dominação de um povo por outro, ainda que imposta pela força das armas, é sempre exercido pela força da cultura. A religião, a língua e o refinamento artístico passaram a ser elementos de dominação dos povos mais fortes. Por outro lado, a religião local, o idioma local e as artes locais, em contrapartida, passaram a ser elementos de resistência dos povos mais fracos à dominação dos mais fortes.

Neste permanente choque cultural passa a se colocar uma nova questão para Humanidade: cada grupamento humano passa a compreender a importância da preservação das formas e expressões de sua própria cultura. Esta auto-preservação passa a ser elemento vital na sobrevivência história das Nações. Esta é a razão que explica a sobrevivência das religiões, mitos, saberes e danças africanas nos países americanos, apesar do sincretismo e das profundas diferenças existentes entre as diversas Nações negras capturadas como escravos no século passado. Isto explica também como os índios americanos (das três Américas) conseguiram resistir culturalmente à avalanche de dominação iniciada no século XVI e que persiste até hoje.

A sociedade moderna começou a tratar desta questão com o ímpeto de resistência e com o instinto de preservação característico não apenas dos homens, mas de todos os animais. Mas não só, a sociedade moderna começou a preservar os bens representativos da cultura como forma de homenagem ao gênio criador do homem e à sua extraordinária capacidade de transformar as coisas, de ligar elementos de cor, textura, flexibilidade, iludindo-se que com a transformação da aparência, consegue transformar a essência mesma das coisas. Essa capacidade transformadora e criadora do homem se manifesta, na verdade, em cada balaio, em cada veste, em cada instrumento de trabalho, em cada manifestação do saber. Mas a principal vontade de preservação de cultura, na sociedade moderna, se volta para as peças únicas, para as obras de arte, as "obras primas", assim chamadas, que tem a capacidade de conter em si a representação de toda a cultura de uma época, de galvanizar o saber humano.

Evidentemente, à vontade social da preservação do patrimônio cultural correspondeu a sua normatização jurídica. Embora se tenha notícia de legislação de tutela de monumentos antigos e de regulamento de escavações de antiguidades, desde 1425, no 
Estado Pontifício, é somente em 1602 que o Estado de Toscano regulamenta a exportação de pinturas e em 1624 o Estado Pontifício proibia a exportação de objetos provenientes de escavações. A partir daí, a legislação, apesar de pouca, foi se aperfeiçoando, até precisar os contornos do patrimônio histórico como bens de interesse público, e, portanto, protegido, independentemente do conceito de propriedade privada e da ação avassaladora do homem.

A questão da preservação cultural entra no Direito como uma autêntica subversão conceitual. Os velhos conceitos de propriedade privada, de domínio público, de intervenção do Estado, são exíguos para reter o enorme conteúdo da cultura de um povo:

Muitos são hoje os problemas legislativos e doutrinários a respeito do patrimônio cultural, muitas vezes a questão é estudada conjuntamente com o Direito Urbanístico, porque grande parte dos monumentos preserváveis são estruturas arquitetônicas. Porém, mais recentemente, a preservação do patrimônio cultural tem sido objeto de estudo conjunto com a preservação do meio-ambiente, do qual, sem dúvida, a cultura é parte integrante. Nessa preservação surge o inevitável choque do interesse social com o interesse individual, e é esse choque que o Direito procura se não diminuir, pelo menos organizar.

\section{2 - O MEIO-AMBIENTE. O PATRIMŌNIO CULTURAL. OS BENS CULTURAIS}

O meio-ambiente, entendido em toda sua amplitude, compreende toda a natureza e a intervenção que nela produz o homem. Assim, compõe o meio-ambiente o solo, a água, o ar, a flora e a fauna, as edificações, as obras de arte e os elementos subjetivos e evocativos, como a beleza da paisagem ou a lembrança do passado, inscrições, marcos ou sinais de fatos naturais ou da passagem do Homem.

Em classificação meramente didática, se entende por meioambiente natural o solo, a água, a flora e o ar. Por meio-ambiente artificial, aquilo que foi construído pelo homem. Finalmente, por meio-ambiente cultural, o patrimônio histórico, paisagístico e arqueológico, na maior parte das vezes artificial, muito embora haja patrimônio cultural natural, dos quais um exemplo de rara grandeza é o complexo de Vila Velha, a 80 km de Curitiba. 
A maior parte dos autores atualmente entende o conjunto do patrimônio cultural e ambiental com a mesma ênfase de interesse de proteção, pela íntima ligação existente, embora na prática administrativa sejam órgãos totalmente distintos os que tratam de preservação do meio-ambiente natural e cultural. Os órgãos de proteção do meio-ambiente natural tem se agrupado aos setores de política agrícola ou fundiária ou ao chamado $\mathrm{Mi}$ nistério do Interior. A preservação cultural tem ficado a cargo da Educação e Cultura.

Porém, a mesma ação predatória do homem que degrada o meio-ambiente destruindo seus elementos para transformá-los em matéria prima ou insumo de produção, degrada também o patrimônio cultural. Esta degradação do meio-ambiente natural ou cultural não é um ato de pura maldade, mas a conseqüência de um sistema de produção que necessita produzir maior quantidade em menor tempo, pelo menor preço. Dentro deste sistema não há lugar para processos e técnicas que encareçam ou limitem a produção. $\mathrm{O}$ sistema econômico que regula a produção de bens é gerador de lucro e não de bens, neste sentido, as indústrias se preocupam menos com as conseqüências poluidoras ou degradadoras de sua ação do que com os resultados efetivos do rendimento do capital.

Para controlar essa constante busca de lucros e degradação da natureza, é necessária a intervenção do Estado, cada vez mais fortemente. "A proteção ambiental, abrangendo a preservação da natureza em todos os seus elementos essenciais à vida humana e à manutenção do equilíbrio ecológico, tem preocupado seriamente o Poder Público diante do ímpeto predatório do homem civilizado, que, em nome do progresso, devasta florestas, exaure a terra, extermina a fauna, polui as águas e a atmosfera" (Hely Lopes Meirelles, Direito Administrativo Brasileiro, 4a. ed. at., 1976 , p. 535).

Este exercício da tutela do meio-ambiente pelo Estado, no Brasil, é relativamente recente. Foi somente na década de trinta, com o primeiro Código Florestal (1934), com o Código de Águas (1934 e ainda em vigor) e com o Código de Pesca (1938, grande parte ainda em vigor) que se iniciou a tutela. Antes era o império do individualismo, do absolutismo da propriedade privada.

Todos estes diplomas, porém, não têm como finalidade a tutela do meio-ambiente, apenas circunstancialmente é que certas normas o protegem diretamente. É muito recente a concepção da necessidade de estabelecer como objeto de tutela jurídica o meio- 
ambiente. Somente na década de 60 se inicia uma presença legislativa voltada à preservação do meio-ambiente. Em 1961 foram criados mais parques nacionais e reservas florestais que no resto da história do Brasil, além das dezenas de florestas declaradas protetoras. Em 1965 é promulgado o novo Código Florestal (Lei 4.771, de 15.09.65), que institui, no artigo 10.: "As florestas existentes no território nacional e as demais formas de vegetação, reconhecidas de utilidade às terras que revertem, são bens de in teresse comum a todos os habitantes do País, exercendo-se os direitos de propriedade com as limitações que a legislação em geral e especialmente esta lei estabelecem". Com esta definição se abria um novo capítulo na história da preservação ambiental no Brasil, a partir daqui o conceito de bem de interesse comum (ou bem de interesse público) passa a ser cotejado com dois conceitos tradicionais - o conceito de domínio público e o conceito de propriedade privada.

Dentro deste mesmo contexto se insere o patrimônio cultural, que não é, nem mais nem menos do que a intervenção do homem na natureza, intervenção física ou abstrata, aquela, as edificações, transformações e obras, estas as técnicas, o saber e o saber fazer, a valoração, o reconhecimento e a identificação. A proteção do patrimônio cultural, no Brasil, antecede à proteção ao meio-ambiente. A lei protetora é de 1937, mas tem como caráter essencial a tutela do patrimônio cultural.

A preservação do Patrimônio Cultural não pode ser, porém, global, porque implicaria em imaginar uma sociedade estática, se todas as intervenções do homem na natureza fossem preservadas não havia nenhuma possibilidade de mudança, a sociedade não poderia evoluir. Se o processo textil tivesse que ser preservado, não haveria com certeza a máquina a vapor, porque esta surgiu em substituição aos velhos métodos manuais de fiação. Exatamente por isto, a preservação do patrimônio cultural é feito da individuação de bens que de uma forma ou outra tornam-se representativos da história da transformação da sociedade humana.

É de se verificar que o meio-ambiente, independente da intervenção do homem, pelo próprio funcionamento do sistema ecológico, está em constante mutação e não é possível sequer imaginar sua preservação como um todo, o que implicaria em estabelecer um status quo imutável. Por isso, é fundamental individuar o que deve ser preservado, o que tem interesse público de preservação. 
À parcela do Patrimônio Cultural e Ambiental individuada com interesse de preservação emprestou do direito o seu nome: bem, agregado o qualificativo de cultural.

O Bem Cultural é um conceito jurídico e o fato de ser cultural é apenas uma qualidade sua, que não exclui outros qualificativos, como móvel e imóvel, público ou privado, fungível e infungível, tudo isto visto enquanto bem físico, real, material. A essência jurídica, porém, tem bem outra situação: a qualidade cultural transforma o bem, atribuindo-Ihe interesse público, infungibilidade e especial proteção jurídica.

\section{3-O BEM CULTURAL}

\section{Os Bens Móveis e os Imóveis}

O Bem Cultural pode ser móvel ou imóvel. Entre os bens móveis se encontra uma categoria especial de bens que são as "obras de arte", normalmente expressões de artes plásticas como a pintura e a escultura. A preservação desta classe de bens é tutelada pelo Estado há muito tempo, com a instituição de museus, de normas proibindo exportação, etc. Já em 1425 o Estado Pontifício editou leis tutelando os monumentos antigos e o produto das escavações de antiguidades; na Toscana, a regulamentação de pinturas foi regulamentada em 1602; na Emilia se estabeleceu normas para exportação de obras de arte em 1760 e em Veneto se estabeleceu um sistema de catalogação e de vínculo para as obras de arte em 1773 (cf. Adiano La Regina, Preservação e Revitalização do Patrimônio Cultural na Itália).

Os outros bens culturais móveis não têm tido a mesma sorte, e somente têm sido protegidos pelo eventual uso que ainda tenham ou pelo possível valor de mercado, como antiguidade, sempre, como se vê, do ponto de vista privado. O poder público, exceção feita às coleções de museus, apenas muito recentemente começa a se interessar na preservação de bens culturais móveis.

Por muito tempo, e ainda hoje alguns autores consideram que preservação dos bens culturais se confunde com a preservação ambiental urbanística, ou arquitetônica. Embora os órgãos oficiais encarregados da preservação no Brasil comecem a entender que a arquitetura seja apenas um, e eventual, elemento de preservação, praticamente toda a doutrina e a legislação levam em conta os bens culturais imóveis. É esta concepção que faz com 
que o Prof. José Afonso da Silva entenda os bens culturais ambientais como imóveis: "Os bens culturais ambientais são de natureza imobiliária, o que Ihe impõe conceito mais restrito do que o patrimônio histórico, arqueológico, etnográfico, artístico e paisagístico, pois este abrange todos os bens, móveis ou imóveis, existentes no país, cuja conservação e proteção sejam de interesse público".

A razão para o Prof. da Universidade de São Paulo buscar um conceito exclusivamente imobiliário para bens culturais agregando a palavra ambiental - se prende ao fato de seu estudo estar inserido no contexto do direito urbanístico e seu interesse ser a legislação pertinente ao ordenamento de construções de edificações urbanas. Apesar disso, porém, mesmo os arquitetos reconhecem a possibilidade de bens móveis serem também culturais, podendo inclusive serem inseridos no contexto urbano (cujo exemplo são os bondes que servem o Morro de Santa Tereza, no Rio de Janeiro). A tutela que o Estado deve aos bens culturais móveis ou imóveis é exatamente a mesma e os critérios de definição de um bem cultural são os mesmos independentemente de sua característica imobiliária.

\section{OS BENS FUNGIVEIS E CONSUMIVEIS}

Questão de interesse é o estudo da fungibilidade do bem cultural. Se qualquer bem pode ter valor cultural, também o podem os fungíveis. Ocorre que o conceito de fungibilidade é antagônico ao de preservação. Se um bem pode ser trocado por outro sem perder sua essência, e tem por isso o seu caráter de fungível, no momento em que se determina a preservação por ser ele mesmo representativo culturalmente se lhe retira o caráter fungível. Tomemos como exemplo o dinheiro, o mais fungível dos bens. Se se declara de valor cultural qualquer moeda ou nota representativa de dinheiro na verdade se está retirando o caráter de dinheiro daquela peça, ela deixa de ser significante de valor monetário, para ser significante de valor cultural, e imediatamente o ser fungível desaparece, tornando-se o bem insubstituível. Aliás, é esta a lição de Clóvis Bevilaqua: "pode a convenção tornar infungíveis coisas que, naturalmente são fungíveis, desde que determine por sua individualidade coisas, que, mais comumente, se destinam, no comércio e na vida, a uma determinação genérica". (Teoria Geral do Direito Civil, p. 183).

Exatamente o mesmo se pode dizer dos bens consumíveis, 
com maior razão ainda, porque a fungibilidade é uma qualidade inerente ao bem, enquanto resultado de comparação de uma coisa com outra, e a consumibilidade é estabelecida em relação a coisa pela pessoa. Assim ensina também Clóvis que os livros são consumíveis enquanto na prateleira de uma livraria, mas inconsumíveis nas estantes de uma biblioteca porque aí se acham para serem lidos e conservados (cf. ob. cit. p. 183).

\section{O INTERESSE PÜBLICO}

O interesse público é reconhecimento coletivo de que o patrimônio cultural deve ser preservado porque "nele se consubstancia e se reverencia a memória da formação nacional que, por isso, se identifica com a própria nacionalidade" (José Afonso da Silva, Direito Urbanístico Brasileiro, p. 492):

$\mathrm{O}$ interesse público, porém, tem graduações e especificidade no tempo e no espaço. Muitas vezes o interesse de uma comunidade choca-se com o interesse de outra, apesar de ambos poderem ser caracterizados como interesse público. Na preservação do meio-ambiente e do patrimônio cultural este choque de interesses é constante. Por isso mesmo, se faz necessário salientar a existência de um interesse público meramente local, outro municipal, estadual, regional, federal e finalmente internacional.

Ocorrem casos em que um bem localizado seja protegido pela vontade coletiva local, da comunidade ou bairro. Esses bens, via de regra, dizem respeito à história local e são marcos que interessam àquela comunidade, muitas vezes em conflito até com interesses públicos maiores; na maior parte das vezes, e pelo interior do Brasil, o interesse local se confunde com o Municipal. A preservação e tutela do bem cultural de interesse municipal compete à Administração Municipal, que para tal tem competência e deve editar leis de proteção.

De uma forma geral se pode dizer que os interesses municipais, estaduais e federal são parcelas de um mesmo todo, mas são comuns os casos de conflito entre estes interesses. Via de regra, o bem declarado de interesse de preservação federal, coincide com os interesses estaduais e municipais, e, ao contrário, os municipais só raramente são reconhecidos pelo Estado e pela União. A forma como se interligam estes interesses, veremos no capítulo pertinente à intervenção da Administração Pública na tutela dos bens culturais. 
Da mesma forma que uma comunidade localizada expressa seu interesse preservacionista, a comunidade das Nações começa também expressar e definir os bens que compreende o Patrimônio Cultural da Humanidade, fazendo com que haja uma instância de preservação acima dos Estados nacionais. Isto tende a ter tanto maior valor quanto a rapidez que os meios de comunicação imprimem ao contato entre os povos. Este estreitamento de contato faz com que a humanidade se identifique como tal sendo os regionalismos apenas parcelas de um complexo cultural universal. Por esta razão a UNESCO editou a "Convención sobre la protección del patrimonio mundial, cultural y natural" aprovada pela Conferência Geral, em 17a. reunião, em Paris, em 16 de novembro de 1972, de que o Brasil é signatário e cujo texto foi aprovado pelo Decreto Legislativo 74, de 30 de junho de 1977.

\section{PROPRIEDADE PÚBLICA E PROPRIEDADE PRIVADA}

O patrimônio cultural nacional é compreendido por um complexo de bens que podem pertencer à União, aos Estados e aos Municípios ou a particulares. Quanto à propriedade, os bens culturais podem ser públicos ou privados.

Apesar disto, todos estes bens são gravados de um especial interesse público - seja ele de propriedade de um ente público ou de particular. Por isto mesmo a doutrina começa a definir uma nova categoria de bens, de grande interesse público e que dizem respeito, especialmente aos bens ambientais e culturais (cf. Sandulli, Gastone Pasini e entre nós José Afonso da Silva): "A doutrina vem procurando configurar outra categoria de bens, os bens de interesse público, na qual se insere tanto os bens pertencentes à entidades públicas sujeitos a regime publicístico, como os bens dos sujeitos privados subordinados a uma particular disciplina para a consecução de um fim público" (José Afonso da Silva, Aspectos Jurídicos do Patrimônio Ambiental, p. 8).

A criação de uma categoria de bens de interesse público não é apenas um mero controle ou exercício do poder de polícia da administração sobre o bem, mas é algo muito mais profundo que incide diretamente na titularidade do bem. Vale a pena, neste particular reproduzir mais algumas palavras do Prof. José Afonso da Silva: "Enquanto o conceito pacífico e geral da função social da propriedade privada se traduz essencialmente na imposição, ao titular do direito sobre a coisa, de certas obrigações pessoais (ob rem), de modo a tornar socialmente útil a titularidade priva- 
da do direito mesmo, mas não se traduz num regime especial da coisa em si, a configuração de uma categoria de bens privados com especificação pública pressupõe um regime especial de tal sorte que eles assumem institucionalmente a finalidade do interesse público e, por isso, são subordinados a um particular regime relativamente à sua disponibilidade (vínculo de destinação, de imodificabilidade, etc, direito de prelação da administração, etc.) e também a um particular regime de polícia, de intervenção e de tutela pública" (idem, ibidem). Conclui o Professor da Universidade de São Paulo que dada essa intervenção direta traduzida como "um regime especial da coisa em si", constituindo mais do que meras obrigações pessoais conseqüentes da função social da propriedade. Esse regime especial condiciona a atividade e os negócios relativos aos bens de interesse público com dois objetivos: controlar a circulação jurídica do bem ou controlar-lhe o uso. Como conseqüência desses dois objetivos surgem duas categorias de bens privados de interesse público: os de circulação controlada e os de uso controlado.

Outra opção doutrinária seria a passagem para o patrimônio público de todos os bens de interesse de preservação. Esta solução porém é negativa não só por dificultar a tutela dos bens culturais, que implicaria na impossível aquisição pelo Estado de todo bem assim considerado, como viria a interferir diretamente no momento de criação artística, já que o próprio artista não seria o proprietário de sua criação e, como lembra Piergiorgio Ferri, na fase de criação artística "I'influenza dell'azione pubblica deve manifestarsi con estrema cautela per non superare quel limite altre il quale lo "stato di cultura" transformerebbe la sua funzione di promozione e di diffusione della cultura in una presenza condizionante i suoi orientamenti creativi, ponendosi in contrasto con la libertà dell'arte e della scienza". (I Beniculturali e Ambientali, p. 33/34).

Um parênteses especial nesta qualificação deve ser feito aos bens integrantes dos sítios arqueológicos regulados pela Lei 3.924/61 (ver anexo V) que coloca sob a guarda e proteção do Poder Público os monumentos arqueológicos e pré-históricos. A pesquisa e o achado arqueológico diretamente interessam ao Patrimônio Cultural e o integram de tal forma que a sua transferência ao domínio privado pode trazer danos irreparáveis à nossa cultura, como foi o caso dos verdadeiros saques aos sambaquis de Laguna, S. C.. A Lei 3.924/61, conhecida como a lei dos sambaquis, distinguiu as jazidas em manifestadas e não manifes- 
tadas. Todas as jazidas existentes e em exploração na data da expedição da lei serão fiscalizadas na "salvaguarda do interesse da ciência" e devia ser manifestada pela então Diretoria do Patrimônio Histórico e Artístico Nacional. As não manifestadas são bens patrimoniais da União.

Quase todas as legislações protetoras do Patrimônio Cultural estabelecem o direito de prelação como inerente ao sistema jurídico dos bens culturais. No Brasil, o Decreto-Lei no. 25, de 30.11.37 (ver anexo II), trata com destaque o direito de preferência atribuindo-Ihe o "status" de capítulo. Este direito de preferência é uma garantia especial e indica, nas legislações, que a comercialização dos bens culturais deve ser evitada, porque gera possível especulação. Hoje, as legislações de praticamente todos os países são voltadas para uma interferência ativa do poder público nos regimes de propriedade dos bens culturais.

\section{4 - A MEDIDA DE VALOR DOS BENS CULTURAIS}

A pedra angular de todas as doutrinas econômicas, é a teoria do valor. Mas todas as teorias analisam o valor dos bens enquanto mercadorias, enquanto elemento de troca dentro de um sistema econômico que tem na produção e circulação de bens a sua fonte.

Mas os bens não têm apenas valor de troca. Para um sedento, um copo de água vale infinitamente mais do que um copo de ouro, mas este valor ocasional que se agregou ao copo de água deixa de existir, saciada a sede. Além da necessidade imediata, outros valores são emprestados a determinados bens, retirando significado ao mero valor de troca. Daí toda uma série de valoração subjetiva, sentimental ou emotiva, capaz de agregar novos valores aos bens de forma que valor de troca passa a ser uma simples referência.

Todas as teorias que buscam encontrar o determinante do valor tem prós e contra, de tal forma que passa ser impossível utilizar qualquer delas como medida. Isso ocorre porque em determinado momento, e de forma ocasional, elementos extraeconômicos - morais ou físicos - entram na composição do valor. Neste ponto, algumas teorias econômicas científicas passam a estabelecer uma diferença profunda entre valor e preço, sendo aquele uma magnitude permanente e medida a partir de critérios científicos e este a expressão monetária de troca. 
Assim, valor é a quantificação precisa de um bem, enquanto preço é a quantidade de dinheiro pela qual se pode trocar o bem em determinadas circunstâncias.

Quando determinado bem é declarado de interesse de preservação seu valor imediatamente aumenta, porque se Ihe agregam valores morais, sentimentais e culturais além de seu valor intrínseco. Mas o mesmo não ocorre, necessariamente, com seu preço, que pode variar ou não .

Sendo o valor um elemento perene, o que se lhe agrega ou se Ihe retira, se faz na mudança da própria essência do bem. Muito ao contrário, a alteração do preço se dá na alteração da circunstância de mercado, vale dizer, alteração da situação externa ao bem. São infinitas as circunstâncias em que a alteração de situação de mercado influi diretamente na questão dos preços. Chuvas de pedra nos EE.UU podem fazer elevar o preço da laranja no interior de São Paulo. A abertura de extensos cacaueiros na Bahia levam à beira da falência governos da África pela baixa do preço do cacau, base de sua economia. Assim, a declaração de interesse de preservação de uma casa, embora the agregue ou reconheça valor, pode fazer com que seu preço baixe, tendo em vista a maior dificuldade de comercialização em conseqüência da obrigatoriedade de preservação. Exatamente por isto, a análise de valor e preço tem especial importância para a questão da verificação da responsabilidade patrimonial do Estado ao declarar um bem de interesse de preservação.

Visto o valor e o preço, há que se analisar, ainda, a questão da utilidade - ou o valor de uso - como o chama a economia política. Um bem declarado de interesse de preservação pode ter - e o tem normalmente - o seu uso restringido. Como o bem não pode ser demolido, modificado em sua estrutura ou acrescido de nova construção, fica evidentemente restrito às possibilidades que já oferece, não podendo ser reformado para facilitar novos usos. Esta vedação à reforma é um problema menor comparado com a eventual possibilidade de nova edificação. Podemos aventar a hipótese de que a região urbana em que se localiza o bem cultural permita edificações de grande porte e este bem seja uma casa térrea. Está claro que se fosse permitida sua demolição, uma nova construção poderia render ao proprietário um expressivo preço a mais. Este corte ao valor de uso potencial do bem, pretendem alguns autores que seja indenizado pelo Poder Público. No capítulo pertinente à responsabilidade patri- 
monial do Estado pelo patrimônio cultural, analisaremos mais de perto esta questão.

\section{5 - A TUTELA E A INTERVENÇĀO DO ESTADO NOS BENS CULTURAIS}

Cinco diplomas legais básicos integram o corpo de leis federais que regulam a tutela e a intervenção do Estado nos bens culturais: a Constituição Federal, artigo 180 e seu parágrafo único; os decretos-leis 25/37 e 3.866/41 e as leis 3.924/61 e 6.292/75; além de um elenco de portarias, decretos e mesmo leis que incidentalmente tratam da questão ou promovem proteção específica a determinado bem. Inclui neste elenco o Código Penal Brasileiro.

No âmbito estadual e municipal, um magro volume de pouco mais de 200 páginas organizado pela Universidade de São Paulo reúne 37 diplomas incluindo decretos especiais de proteção de sítios, que nem de longe cobrem os 23 Estados e os mais de 50 Municípios com mais de $\mathbf{2 5 0 . 0 0 0 ~ h a b i t a n t e s . ~ D a i ́ ~ a ~ p o b r e - ~}$ za de legislação de tutela de patrimônio cultural entre os Estados e Municípios.

$\mathrm{O}$ artigo 180 da Constituição Federal em vigor, segundo a redação que the deu a emenda no. 1, de 17.10.69 é taxativo: "O amparo à cultura é dever do Estado" e o seu parágrafo único: "Ficam sob a proteção especial do poder público os documentos, as obras e os locais de valor histórico ou artístico, os monumentos e as paisagens naturais notáveis, bem como as jazidas arqueológicas".

José Afonso da Silva alerta no sentido de que a doutrina e a jurisprudência brasileiras não têm percebido o profundo alcance deste dispositivo constitucional. Esta norma não é uma mera disposição programática, mas se reverte de eficácia ao impor ao poder público a obrigação de proteger o patrimônio cultural, indicando-Ihe, portanto, uma conduta positiva. Por outro lado, subordina a propriedade privada a um regime jurídico especial, não se trata de simplesmente condicionar a propriedade privada à sua função social, mas sim de subordiná-la a um regime especial, como bem de interesse público.

Nesse mesmo sentido se refere Pontes de Miranda em comentário a este artigo da Carta Constitucional: “Desde que, na propriedade de alguém, existe monumento histórico, móvel ou 
imóvel, que o Estado repute digno de guarda ou de proteção, nenhum direito tem o proprietário, ainda fora dos casos de desapropriação, para obstar ao exercício de qualquer medida de proteção ou zelamento" (Pontes de Miranda. Comentários à Constituição de 1967, com a Emenda no. 1, de 1969).

Para que recaia todo esse sistema de proteção a um bem determinado, é necessária uma manifestação da Administração, a edição de um ato administrativo que faça sua inscrição num dos livros do Tombo, conforme determina ainda hoje o velho Decreto-lei no. 25, de 1937 (ver anexo II). Este ato, por ser de inscrição no livro do Tombo, se chama no Brasil, tombamento.

Discussão que polariza a opinião dos juristas é definição da natureza jurídica do tombamento. Forte e antiga corrente entende que o tombamento é um ato declaratório (entre nós Hely Lopes Meireles e em certo sentido Pontes de Miranda, entre os italianos Biamonti, Calamandrei, Giannini, Palma, Alibrandi, Piergiorgio Ferri). Entendem estes autores que o tombamento é uma mera declaração de que determinado bem tem em si valores que são reconhecidos como históricos ou artísticos, neste sentido é uma declaração de interesse público qualificado, que acresce ao bem um atributo de caráter puramente jurídico. Alibrandi sustenta que o tombamento é um ato declaratório porque agrega ao bem apenas "una valutazione (giudizio) dell amministrazione competente (I Beni Ambientali e Culturali, p. 240).

Em sentido diverso, entendem outros autores que a natureza jurídica do tombamento é constitutiva. O Fundamento desta doutrina é que é $o$ ato da Administração que constitui o bem como integrante do patrimônio histórico, arqueológico e paisagístico. (Neste sentido, entre os brasileiros, Cretella Junior e José Afonso da Silva, entre os italianos Sandulli, Cantucci e Bile). No dizer de José Afonso da Silva, o tombamento "produz efeitos sobre a esfera jurídica dos proprietários, privados ou públicos, dos bens tombados, impondo limitações ao direito de propriedade, e cria, para eles, um regime jurídico especial, transformandoos em bem de interesse público (situação diversa de domínio público e domínio privado), sujeitos a vínculos de várias espécies. Tudo isto inova a situação jurídica dos bens tombados, transforma sua posição jurídica e impõe a seus proprietários condutas jurídicas, ob rem, que antes não havia, demonstrando que o tombamento, em qualquer caso, é ato constitutivo". (Direito Urbanístico Brasileiro, p. 499-500). 
Cretella Junior é categórico: “o tombamento é ato administrativo unilateral, discricionário e constitutivo", (RDA 112/ 62). Aspecto de fundamental importância é o caráter discricionário do tombamento. Alguns autores consideram que discricionário é apenas o momento da expedição do ato, porque o ato em si é vinculado aos elementos históricos-estéticos do bem, neste sentido, Pontes de Miranda afirma que "O ato estatal não é discricionário. Há o pressuposto de ter valor artístico, ou histórico, ou de beleza natural, o bem que se tomba como monumento ou documento protegido". (Comentários, p. 368).

Porém, Alibrandi se alegra da uniformidade de pensamento na Itália a respeito da discricionariedade do ato de tombamento: "Questa tesi ha ottenuto il conforto di un constante orientamento del Consiglio di Stato, il quale ritiene che il giudizio sull'interesse particolare della cosa rapresenta il risultato de una valutazione tecnico-discrezionale dell'amministrazione, come tale non sindicabile in sede giurisdicionale, se non nei limiti della ligicità del provvedimento e della necessità di una apposita istrutória per l'accertamento dei presuporti ai quali è condizionato l'exercizio del potere". (I Beni Culturali e Ambientali, p. 240).

Essa valoração técnica, que integra, completa e qualifica o caráter discricionário do ato administrativo, não altera sua qualidade discricionária do ato, mas apenas o torna complexo, exigindo a emissão de parecer valorativo, mas continua discricionário o ato, porque a administração pode ou não efetivar o tombamento, assim como pode cancelá-lo, atendendo interesse público.

O tombamento gera efeitos muito precisos e extraordinariamente importantes para o bem tombado e para seu proprietário. Os efeitos podem ser agrupados em três grandes categorias: 1) obrigações e responsabilidades do proprietário, possuidor ou adquirente do bem; 2) limitações e modificações aos direitos sobre o bem; 3) restrições ao bem em si.

As obrigações e responsabilidades dos proprietários, possuidores e adquirentes são basicamente os de conservação do bem e publicidade do fato de ser tombado. O Decreto-lei no. 25/37 estabelece, geral e especificamente, as obrigações de cada pessoa e aplica ele mesmo sanções de multa para a inobservância do que está regulado. $O$ Código Penal Brasileiro tipifica, em seu artigo 165 o crime de dano em coisa de valor artístico, arqueológico ou histórico, e no artigo 166, o crime de alteração do local especialmente protegido (ver anexo VII). 
Por outro lado, à lei estabelece restrição a alienabilidade da coisa tombada, impondo o direito de preferência do Poder Público e sujeitando o adquirente, ainda que a título não oneroso, de comunicar ao órgão competente a transferência e torná-la pública, no registro de imóveis, se for o caso. Sendo o bem pertencente à União, Estados e Municípios fica reafirmada sua inalienabilidade, e a transferência somente é admitida de um destes entes para outro.

O bem fica ainda sujeito à intervenção do órgão promotor do tombamento, seja para vigilância, vistoria, fiscalização ou autorização de eventuais e necessárias intervenções, como restauro, reparações, pinturas, etc.

Por último, o bem, uma vez tombado, é imodificável. No entender de José Afonso da Silva "A imodificabilidade da coisa tombada constitui o vínculo mais rigoroso que deflui o tombamento" (Direito Urbanístico Brasileiro, p. 504). De fato, é taxativo 0 artígo 17 do Decreto-lei 25/37, quanto à proibição de modificar o bem, impondo à qualquer alteração (necessária a sua preservação) prévia autorização do órgão que procedeu ao tombamento.

Há uma limitação imposta na lei aos bens vizinhos ao bem tombado, que restringe seu uso e gozo, já que ficam proibidas construções que reduzam a visibilidade da coisa protegida.

É interessante notar, porém, que o tombamento é apenas um - ainda que o principal - instrumento de proteção de bens culturais de que dispõe o poder público. Ao lado do tombamento, e passível de ser exercido tanto pelo Município quanto pelos Estados e pela União, está a desapropriação por utilidade pública, autorizada pelo Decreto-lei 3.365/41, art. 50., letra "K" (ver anexo (II). Outro instrumento de extraordinária eficácia, restrita porém aos Municípios, é o zoneamento.

A desapropriação, na verdade, é um instrumento que se acopla ao tombamento, Ihe dá mais força, tendo em vista que expropria o bem do patrimônio privado e o transforma em público, fazendo com que seja facilitada a ação preservacionista do Estado. $\mathrm{O}$ zoneamento é instrumento utilizado muito mais para definir áreas de interesse cultural, normalmente históricos, e, assim, facilitar a ação do Poder Público Municipal que, como já foi dito, em sua grande maioria não possui legislação própria para tombamento. 


\section{6 - RESPONSABILIDADE PATRIMONIAL DO ESTADO}

O Estado, na sua ação administrativa, pode causar danos a particulares, porque a sua atividade implica certas limitações coercitivas no direito dos indivíduos. Essa ação do Estado gera obrigações aos particulares de submeter o seu direito ao sacrifício, em razão do interesse público. Esse direito sacrificado, porém, é convertido em seu conteúdo econômico e este conteúdo econômico indenizado pelo Estado.

Esta responsabilidade patrimonial do Estado é gerada por uma ação legítima da Administração, posto que se a ação do Estado é ilegal, outro é o pressuposto da indenização. Neste sentido, o fundamento da responsabilidade patrimonial do Estado por atos lícitos é a idéia jurídica da igualdade de todos os cidadãos perante os ônus públicos, que exclui o "sacrifício especial" sem indenização.

São, portanto, requisitos essenciais para que a ação legítima e danosa do Estado se converta em indenização: "la singularidad del daño, efectividad de la protección jurídica del derecho que se sacrifica y mensuralidad económica del daño". (Fernando Garrido Falla, Tratado de Derecho Administrativo, vol. II, p. 250).

A singularidade do dano sugere que a imposição seja especial, por isto a doutrina brasileira tem preferido o termo especialidade. Significa que as restrições gerais não podem servir de fundamento à indenização, mas o fato de ser singular traduz também uma concretude. $\mathrm{O}$ direito lesado há de ser o direito concreto ou o conteúdo concreto de um direito. Umma limitação a direitos abstratamente considerados tampouco motiva a indenização.

É unânime a doutrina ao considerar que para que haja obrigação de indenizar o sacrifício seja o de um verdadeiro direito e não de expectativas ou simples interesse. É de se ressaltar que devem ser excluídos da indenização os prejuízos que advenham da própria índole do objeto sacrificado, como, num exemplo de Garrido Falla, a proibição ao proprietário de usar como moradia um edifício com risco de ruir.

Além do fato de ser direito verdadeiro e especial, é necessário que se possa medir o dano, quer dizer, o dano há de poder ser avaliado economicamente; em função deste item, ficam fora de indenização as ameaças de dano, os incômodos e os danos morais de impossível avaliação econômica. 
A partir destes pressupostos é que se pode analisar a incidência do tombamento na propriedade privada e a responsabilidade patrimonial do Estado por este ato.

Antes de mais nada é de se dizer que em certos casos pode haver necessidade de expropriar o bem, quer seja por seu extraordinário valor cultural, quer seja pela importância relativa que assume num conjunto determinado, quer seja pelo interesse da administração em dar ao bem uma destinação de uso compatível com seu significado histórico e cultural. Nestes casos, concomitante com o tombamento, o Poder Público deve proceder à desapropriação do bem, de acordo com o Decreto-lei no. 3.365/41, art. 50., "K", "L"e "O" (ver anexo III). Realizada a desapropriação, o tombamento recaìrá sobre o bem público e ficará afastada a hipótese de indenização que não o justo preço da desapropriação.

A hipótese de indenização só ocorre, assim, se o tombamento recair sobre bens de domínio privado desde que a administração entenda que deve continuar sendo propriedade particular. É remota a idéia de indenização pelo tombamento de bens móveis. De fato, os bens móveis tombados ou passam a constituir acervo de museus e são transferidos ao patrimônio público, ou são colocados sob a guarda de órgão público, por meio de comodato, ou se mantém na guarda do proprietário. Apesar disto, os bens móveis sofrem restrições e limitações idênticas aos imóveis, acrescidas das limitações relativas às mudanças de local e a proibição expressa de sua venda ao exterior. Se ocorre o caso de o Poder Público determinar a transferência de bens imóveis tombados à sua guarda, será necessário o uso do instrumento de desapropriação, letra " $\mathrm{L}$ " e "O" do citado artigo 50. do Decreto-lei no. 3.365/41 (anexo III).

A questão de indenização pelo tombamento de bens culturais imóveis é deveras complexa e reduz, em última instância ao grau de intervenção que o ato produz no exercício do direito de propriedade. É assim que o supremo órgão jurisdicional italiano definiu em sentença citada por Gastone Martini que "è da considerarsi como de carattere espropriativo anche l'atto che, pur non disponendo una traslazione totale o parziale di diritti, imponga limitazione tali da svuotare di contenuto il diritto di proprietà, incidendo sul godimento del bene tanto profondamente da renderlo inutilizzabile in rapporto alla destinazione inerente alla natura del bene stesso, o determinando il venir meno, o una penetrante incisione, del sua valore di scambio" (Disciplina Urbanisti- 
ca e tutela del patrimonio storico artistico e paesistico, p. 129).

De fato, a primeira questão de análise é a questão do uso, ou do valor de uso. Se um imóvel tem uma destinação de uso inerente à sua existência, e o tombamento Ihe retira essa possibilidade, é claro que surge daí a responsabilidade do Estado de indenizar. Esta hipótese, porém, no atual conceito de patrimônio cultural, é pouco viável, porque se concebe hoje um bem cultural em seu pleno uso. A moderna idéia de patrimônio cultural repele a possibilidade de que um bem, para ser preservado, perca a sua destinação de uso inerente, até porque, esta destinação de uso, se inerente ao imóvel, é com ele tombado. Se por ventura o ato da Administração vier a proibir o uso atual de um imóvel porque incompatível com sua qualidade de bem tombado, o que tem a Administração a fazer é desapropriar esse direito e não, necessariamente o imóvel. Podemos tomar como exemplo hipotético de um antigo Teatro usado atualmente como comércio; se no ato do tombamento o Estado determina que o seu uso tem que voltar a ser para teatro, proibindo o comércio ali estabelecido, deve desapropriar o fundo de comércio. Parece, porém, que qualquer hipótese nesse sentido é extraordinariamente remota e não encontra respaldo na realidade. Se o Estado ao tombar um imóvel deseja que seu uso seja modificado, será mais correto desapropriálo.

Ao contrário disso, como ficou afirmado acima, pode o poder público tombar um imóvel e o seu uso atual. Por exemplo, tombar um cinema para que continue sendo cinema, assim um teatro, um bar (como é o caso do processo de tombamento do Bar da Lagoa, no Rio de Janeiro), impondo, desta forma, um uso ao prédio, tombando, neste sentido, a função e não o imóvel.

Situação diversa é a alteração não mais no valor de uso do imóvel, mais no seu valor de troca. $O$ tombamento em si não tem o poder de alterar o valor de troca do imóvel, a não ser em duas circunstâncias muito precisas: o alto custo da restauração e a existência de um empreendimento real e concreto prejudicado pelo tombamento.

Algumas vezes o restauro do prédio tombado é um ônus demasiado pesado para o proprietário arcar e se este ônus for tão pesado que ultrapasse em muito o valor de troca da propriedade mesma, o poder tem obrigação de interferir e, neste caso, proceder à desapropriação, porque não pode exigir a obrigação de fazer acima do que seja razoável economicamente. A lei italiana prevê, 
textualmente, a possibilidade de desapropriação do bem para fins de restauro.

Outra situação análoga é a possibilidade de que em função do tombamento algum empreendimento, construção ou negócio seja prejudicado e daí decorra uma necessidade de indenizar. A hipótese de que um prédio vizinho tenha que ser obstado quando já em construção, para não prejudicar a vista do bem que vem a ser tombado ou ainda de uma construção no próprio sítio tombado que fica impedida de continuar ou obrigada demolir, se enquadra perfeitamente nos pressupostos de Garrido Falla para que se imponha uma indenização.

Pelo princípio geral, se dá apenas limitação ao direito de propriedade, não há que se falar em indenização, se ao contrário, há supressão da propriedade, ou de seu valor econômico, estamos diante de um caso de desapropriação. Ou, no dizer do ConsultorGeral Adroaldo Mesquita da Costa: "Quando (. . .) a restrição ou limitação importa, pelo tombamento, no esvaziamento do conteúdo econômico da propriedade, já não há, apenas restrição, senão verdadeira supressão, apreensão, ou outro nome se lhe dê, dessa propriedade (. . . ). Nesse caso o tombamento se equipara a uma desapropriação por utilidade pública". (RDA 82/341).

Nesse mesmo sentido e com muita clareza se expressa Hely Lopes Meireles: "O tombamento, em princípio, não obriga a indenização alguma, salvo se acarretar a interdição do uso normal da propriedade, ou se as condições de conservação da coisa exigirem despesas extraordinárias para o proprietário, caso em que deverão ser suportadas pelo Poder Público, ou realizada a desapropriação do bem tombado (art. 19). (. . .) Mas é de se advertir que a desapropriação da coisa tombada constitui exceção, e só se justifica quando impossível a sua normal utilização pelo proprietário particular, com pleno atendimento de sua destinação histórica ou artística desejada pelo Poder Público". (Direito Administrativo Brasileiro, p. 484).

Sendo assim, embora antiga e em grande medida ultrapassada em seus conceitos básicos, o Decreto-lei no. 25/37, é capaz de, somado ao Decreto-lei no. 3.365/41, permitir que o poder público proteja o patrimônio cultural, impondo limites à propriedade privada, sem necessidade de indenizar, embora disponha de instrumento eficaz - a desapropriação por utilidade pública - se for necessário, para proteger o bem cultural, expropriando-o do regime privado e passando-o ao domínio público. 


\section{BIBLIOGRAFIA CITADA}

- ALIBRANDI, Tommaso e Ferri, Piergiorgio. I beni culturali e ambientali, Milano, Giuffrè Editore, 1978,682 p.

- BEVILAQUA, Clovis. Teoria geral do direito civil. Ed. rev. atual por prof. Caio Mario da Silva Pereira. 2.ed. Rio de Janeiro, Francisco Alves. 1980.342 p.

- COSTA, Adroaldo Mesquita da. Patrimônio histórico e artístico nacional - tombamento - desapropriação, Rio de Janeiro, RDA 82/341-346.

- CRETELLA JR., José. Regime jurídico do tombamento. Rio de Janeiro, RDA $112 / 54$ - 1973.

- FAllA, Fernando Garrido. Tratado de Derecho Administrativo, vol. II. Madrid, Centro de Estudios Constitucionales, 1983,603 p.

- FBCN - Fundação Brasileira para a Conservação da Natureza. Legislação de conservação da natureza, $3^{\mathrm{a}}$. ed., São Paulo, 1983,510 p.

- FAUUSP. Patrimônio cultural - legislação federal 1922-1945, São Paulo, s/d. $204 \mathrm{p}$.

- FAUUSP. Patrimônio cultural - legislação federal 1945-1974, São Paulo, s/d. $173 \mathrm{p}$.

- LA REGINA, Adriano. Preservação e revitalização do patrimonio cultural na Itália. São Paulo, FAUUSP, 1982, 80 p.

- MARTINI, Gastone. Disciplina urbantstica e tutela del patrimonio storico artistico e paesistico, Milano, Giuffrè Editore, 1970, $202 \mathrm{p}$.

- MEIRELlES, Hely Lopes. Direito administrativo brasileiro, 10. ed. at., São Paulo, Ed. Rev. dos Tribunais, 1984,699 p.

- PONTES DE MIRANDA, Comentdrios à constituição de 1967, com a emenda no. 1 de 1969. São Paulo, Ed. Rev. Tribunais, 2. ed. tombo VI, 1972.

- SILVA, José Afonso da. Aspectos jurídicos do patrimônio ambiental. São Paulo. FAUUSP, 1981, 40 p.

- SILVA, José Afonso da. Direito urbantstico brasileiro. São Paulo, Ed. Revista dos Tribunais, $1981.617 \mathrm{p}$. 